\title{
Analisis Kesesuaian Materi Himpunan Buku Teks Siswa Matematika Kelas VII terhadap Kurikulum 2013
}

\author{
Sri Murniati ${ }^{*}$, Yenita Roza², Maimunah ${ }^{3}$ \\ $1^{*, 2,3}$ Program Studi Magister Pendidikan Matematika, Universitas Riau \\ Kampus Bina Widya KM 12.5, Simpang Baru,Tampan, Pekanbaru, Riau, Indonesia \\ 1*sri.murniati7949@grad.ur.ac.id; ${ }^{2}$ yenita.roza@lecturer.unri.ac.id; \\ 3maimunah@lecturer.unri.ac.id
}

Artikel diterima: 01-01-2021, direvisi: 21-05-2021, diterbitkan: 31-05-2021

\begin{abstract}
Abstrak
Buku teks merupakan sarana pendidikan yang standar mutunya perlu diatur. Tetapi kenyataannya guru masih memiliki keluahan mengenai buku siswa Kurikulum 2013. Tujuan penelitian adalah menganalisis kesesuaian Bab Himpunan pada Buku Siswa Matematika untuk SMP/MTs Kelas VII Kurikulum 2013 Edisi Revisi yang ditulis oleh Atang Supriadi dan diterbitkan oleh Grafindo Media Pratama tahun 2019 dengan Kurikulum 2013. Jenis penelitian adalah penelitian kualitatif deskriptif dengan instrumen sesuai dengan 4 kriteria Kurikulum 2013. Instrumen yang digunakan adalah lembar penskoran analisis kesesuaian bab himpunan. Metode pengumpulan data yang digunakan adalah metode dokumentasi dan observasi. Hasil analisis diperoleh 91,67\% untuk kesesuaian dengan SKL, kategori sangat baik; 87,5\% kesesuaian dengan pendekatan saintifik, kategori sangat baik; $81,25 \%$ kesesuaian dengan penilaian autentik, kategori baik; dan 90,9\% kesesuaian dengan kelayakan materi, kategori sangat baik. Buku teks sudah cukup baik dijadikan sebagai sumber referensi yang digunakan dalam pembelajaran matematika, walaupun ada beberapa kekurangan atau ketidaksesuaian dengan Kurikulum 2013. Kata Kunci: Bab Himpunan, Buku Teks Siswa Matematika, Kurikulum 2013.
\end{abstract}

\section{The Analysis of the Suitability of the Material of the Class VII Mathematics Student Textbook Association to the 2013 Curriculum}

\begin{abstract}
Textbooks are educational facilities whose quality standards need to be regulated. But the fact is that teachers still have concerns about the 2013 Curriculum student books. The research aims to analyze the suitability of the Chapters of the Association of Mathematics Student Books for Class VII SMP / MTs of the Revised 2013 Curriculum written by Atang Supriadi and published by Grafindo Media Pratama in 2019 with the 2013 Curriculum The type of research is descriptive qualitative research with instruments by the 4 criteria of the 2013 Curriculum. The instrument used is a score sheet for the set of chapter conformity analyses. Data collection methods used are documentation and observation methods. The analysis results obtained $91.67 \%$ for conformity with SKL, very good category; $87.5 \%$ conformity with the scientific approach, very good category; $81.25 \%$ conformity with authentic assessment, good category; and $90.9 \%$ conformity to the eligibility of the material, very good category. Textbooks are good enough to be used as a reference source used in mathematics learning, even though there are some deficiencies or inconsistencies with the 2013 Curriculum.

Keywords: Association Chapter, Mathematics Student Textbook, 2013 Curriculum.
\end{abstract}




\section{Pendahuluan}

Kurikulum merupakan inti dari proses Pendidikan (Niculescu, 2020; Torkos, 2020). Esensinya, kurikulum membahas proses penyelenggaraan pendidikan sekolah, berupa acuan, rencana, norma-norma yang dapat dipakai sebagai pegangan (Elias, 2019). Secara umum struktur kurikulum mempunyai empat komponen utama, yaitu tujuan, materi/ bahan (organisasi isi), proses belajar mengajar, dan evaluasi (Nurdin, Syafruddin, \& Adriantoni, 2016).

Untuk menghadapi kemajuan teknologi informasi dan kurangnya mutu pendidikan dimasa sekarang ini, pemerintah mengeluarkan kebijakan baru yaitu membuat kurikulum baru yang merupakan rujukan dari Kurikulum Berbasis Kompetensi (KBK) ke Kurikulum Tingkat Satuan Pendidikan (KTSP) dan yang baru diterapkan adalah kurikulum 2013 (Fatimah, 2021). Kurikulum 2013 yang mulai diterapkan pada tahun pembelajaran 2013/2014 untuk memberikan perubahan yang sangat mendasar pada pendidikan dasar dan menengah. Kurikulum 2013 yang lebih menekankan terhadap pendidikan karakter siswa (Hakim, 2017; Abi, 2017).

Kurikulum 2013 yang berbasis karakter dan kompetensi, berguna untuk meningkatkan kemampuan mutu dalam proses dan hasil pembelajaran yang memiliki tujuan untuk membentuk akhlak mulia dan budi pekerti pada siswa secara utuh, terpadu, dan seimbang, menganalisis dan menginternalisasi nilai-nilai karakter dan akhlak mulia agar dapat diimplikasi dalam kehidupan sehari-hari (Hildani \& Safitri, 2021).

Kurikulum 2013 yang berbasis karakter dan kompetensi juga, diantaranya keinginan untuk memberi perubahan pada pola pendidikan orientasi terhadap hasil dan materi kependidikan sebagai proses, melalui pendekatan tematik integratif (Habiby, 2017). Dengan demikian, dalam pembelajaran sangat banyak melibatkan peserta didik, agar siswa dapat mengeksplorasi dalam membentuk kompetensi dengan menggali berbagai kemampuan yang dimiliki siswa.

Penerapan Kurikulum 2013 dalam pembelajaran matematika, pemerintah sangat mengharapkan peningkatan kreatifitas dalam pembelajaran dan berpartisipasi pada masyarakat, bangsa dan negara sehingga siswa dapat mempersiapkan diri dengan berbagai kemampuan baik dari dimensi pengetahuan, sikap, dan keterampilan yang berkembang sesuai dengan perubahan peradaban dan zaman (Kemendikbud, 2013).

Dalam Permendikbud Nomor 81A Tahun 2013 tentang implementasi Kurikulum berisi tentang lima lampiran (Restian, Deviana, \& Saputri, 2020), yaitu a) mengenai pedoman dalam mengembangkan kurikulum tingkat satuan lembaga atau satuan pendidikan, b) mengenai pedoman dalam pengembangan muatan lokal, c) mengenai pedoman aktivitas ekstarkulikuler, d) mengenai pedoman umum pembelajaran, dan e) mengenai pedoman dalam evaluasi kurikulum. Untuk lampiran a, b, c, dan e digunakan oleh Satuan Pendidikan/ Lembaga Pendidikan sedangkan untuk lampiran e bisa digunakan oleh guru/ pendidik yang meliputi perencanaan pembelajaran seperti RPP dan Silabus, 
dalam proses pembelajaran sampai evaluasi pembelajaran.

Untuk perangkat lain yang menunjang penerapan Kurikulum 2013, terdapat buku teks yang dibuat oleh pemerintah untuk guru dan siswa. Buku siswa ini berisi mengenai upaya yang harus dilakukan siswa untuk mencapai kompetensi yang terdapat di dalam Kurikulum 2013 (Yunianto, 2021). Dalam pembelajaran, siswa dituntut agar mendapatkan dan mengumpulkan informasi dari berbagai sumber belajar yang ada disekitarnya (Afriansyah, Herman, \& Dahlan, 2021). Untuk mewujudkan keberhasilan penerapan Kurikulum 2013 ini, berbanding lurus dengan kreativitas guru merupakan salah satu faktor penting yang memiliki pengaruh besar dalam pembelajaran (Mukminah, 2018). Karena, peranan guru sebagai yang merencanakan, melaksanakan, dan mengembangkan kurikulum dalam pembelajaran walaupun guru bukan sebagai pelopor konsep-konsep tentang kurikulum. Dengan demikian, guru merupakan fasilitator dalam pembelajaran, perlu memperhatikan terlebih dahulu buku siswa maupun buku untuk pegangan guru yang telah diberi oleh pemerintah (Pardi \& Mauliddin, 2021). Hal ini sangat diperlukan karena buku yang tersedia dari pemerintah berskala nasional. Oleh karena itu, sebelum digunakan, guru dianjurkan untuk membaca dan mencermati dengan menganalisis buku tersebut terlebih dahulu.

Buku teks yang telah disediakan untuk pembelajaran matematika seperti yang tercantum dalam Peraturan Pemerintah Nomor 19 Tahun 2005 mengenai Standar
Nasional Pendidikan bahwa buku teks merupakan sarana pendidikan yang standar mutunya perlu diatur yaitu meliputi standar isi, standar proses, standar kompetensi lulusan, standar pendidikan dan kependidikan, standar sarana dan prasarana, standar pengelolaan, standar pembiayaan, dan standar penilaian pendidikan. Akan tetapi, dalam kenyataannya, guru masih memiliki keluhan mengenai buku siswa Kurikulum 2013 seperti terdapatnya kesalahan penulisan, jawaban dari contoh soal, maupun kesalahan konsep (Sunuyeko, Lani, \& Wahyuni, 2017).

Dalam penelitian Rizkianto \& Santosa (2017), masih banyak kesalahan di dalam buku teks siswa seperti kesalahan penulisan kalimat, tidak jelasnya perintah yang ada pada soal, terdapat kesalahan perhitungan, terdapat kesalahan pada ilustrasi, dan kesalahan konsep pada kompetensi dasar. Sedangkan dalam penelitian Ramda (2017) menyatakan bahwa buku teks matematika kelas VII edisi revisi tahun 2014 belum sepenuhnya sesuai dengan standar isi, standar proses, dan standar penilaian dalam Kurikulum 2013. Oleh karena itu, diperlukan tindakan yang pasti agar guru dan siswa mudah dalam mempelajari matematika.

Dalam penelitian ini yang akan dibahas adalah analisis kesesuaian buku teks pada materi Himpunan dengan Kurikulum 2013. Bila dibandingkan dengan penelitianpenelitian sebelumnya, yaitu penelitian yang dilakukan oleh Rizkianto \& Santosa (2017) dan penelitian Ramda (2017), pada penelitian tersebut dibahas lebih kompleks analisisnya tidak terfokus pada salah satu 
materi pada buku teks. Jadi perbedaan dengan penelitian sebelumnya yaitu peneltian ini khusus pada materi Himpunan saja yang terdapat pada buku teks matematika kelas VII Kurikulum 2013 yang ditulis oleh Atang Supriadi dan diterbitkan oleh Grafindo Media Pratama tahun 2019.

Mengingat sangat pentingnya buku siswa dalam pembelajaran matematika, perlu dilakukan analisis buku teks matematika (Van Zanten \& van den HeuvelPanhuizen, 2018; Glasnovic Gracin, 2018). Melihat banyaknya buku teks matematika yang beredar di pasaran, sehingga harus selektif dalam memilih buku teks tersebut. Buku teks dengan kelayakan yang baik, harus memiliki daya tarik dan dapat merangsang minat siswa sehingga motivasi siswa untuk belajar semakin meningkat (Sari \& Suryana, 2019; Anwar, dkk., 2019). Dalam menganalisis buku teks pelajaran matematika, menggunakan indikator yang tercantum dalam Peraturan Menteri Pendidikan dan Kebudayaan Nomor 22 Tahun 2016 tentang Standar Proses Pendidikan Dasar dan Pendidikan Menengah (Utari \& Hartono, 2019), yaitu: 1) sesuai dengan Standar Kompetensi Lulusan; 2) pendekatan yang digunakan dalam penerapan Kurikulum 2013 adalah pendekatan saintifik; 3) penilaian autentik, dan 4) kelayakan buku dilihat dari aspek materi dan aspek penyajian materi. Keempat kriteria tersebut, akan digunakan untuk menganalisis kesesuaian buku teks siswa matematika untuk SMP/MTs Kelas VII Kurikulum 2013 Edisi Revisi pada materi himpunan yang ditulis oleh Atang Supriadi dan diterbitkan oleh Grafindo Media Pratama pada tahun 2019.
Hasil analisis dalam penelitian ini menunjukkan buku teks matematika untuk kelas VII pada materi Himpunan yang ditulis oleh Atang Supriadi, cukup baik untuk dapat digunakan oleh siswa dan guru dalam pembelajaran karena memiliki kesesuaian dengan kurikulum 2013. Walaupun ada beberapa aspek yang masih kurang dan belum ada kesesuaian dengan Kurikulum 2013. Hal ini bisa menjadi salah satu referensi dalam menentukan sarana pembelajaran berupa buku teks untuk memfasilitasi siswa dan guru dalam mencapai tujuan pembelajaran.

Kesesuaian dengan Standar Kompetensi Lulusan yang meliputi 3 ranah, yaitu ranah pengetahuan (kognitif), ranah sikap (afektif), dan ranah keterampilan (psikomotor). Ketiga ranah ini didapatkan melalui proses psikologi yang berbedabeda. Untuk ranah pengetahuan meliputi kegiatan mengingat, memahami, menerapkan, menganalisis, mengevaluasi dan menciptakan yang terdapat dalam Kompetensi Dasar. Untuk ranah sikap meliputi kegiatan menerima, menjalankan, menghargai, menghayati, dan mengamalkan yang terdapat dalam Kompetensi Inti. Sedangkan untuk ranah keterampilan meliputi kegiatan mengamati, menanya, mencoba, menalar, menyaji, dan menciptakan.

Pendekatan saintifik merupakan pembelajaran yang berdasarkan prinsipprinsip keilmuan yang memiliki beberapa aktivitas yang seperti mengamati, menanya, mengumpulkan informasi, mengasosiasikan atau mengolah informasi, dan mengkomunikasikan (In'am \& Hajar, 2017; Rapanta, dkk., 2020). Agar pendekatan saintifik semakin kuat, maka 
perlu untuk menerapkan pembelajaran discovery learning (Ibanez \& Delgado-Kloos, 2018). Sedangkan, agar meningkatnya kemampuan siswa dalam menghasilkan karya kontektual secara individual ataupun kelompok maka sangat dianjurkan menggunakan pendekatan pembelajaran yang bisa menghasilkan karya berbasis pemecahan masalah atau project based learning (Brassler \& Dettmers, 2017; Wu \& $\mathrm{Wu}, 2020)$.

Menurut Kunandar (2013), penilaian autentik merupakan aktivitas untuk menilai siswa yang lebih ditekankan pada apa yang akan dinilai, yang meliputi proses ataupun hasil dengan menggunakan instrumen yang sesuai dengan Standar Kompetensi (SK) atau Kompetensi Inti (KI) maupun Kompetensi Dasar (KD). Dengan kata lain, penilaian ini diperoleh melalui penerapan pengetahuan, sikap, dan keterampilan yang dimiliki oleh siswa dalam pembelajaran. Penilaian autentik ini menginginkan agar siswa menunjukkan kombinasi kinerja antara pengetahuan dan keterampilan secara nyata dan bermakna. Penilaian autentik ini, dilakukan saat proses pembelajaran berlangsung dan sesudah proses pembelajaran. Penilaian autentik ini terdiri dari 4 macam yaitu penilaian kinerja, penilaian proyek, penilaian portofolio, dan penilaian tertulis yang meliputi ranah pengetahuan, sikap, dan keterampilan.

Dalam Permendikbud Nomor 8 Tahun 2016, kelayakan buku yang terlihat dalam aspek materi meliputi a) tetap terjaganya kebenaran dan keakuratan materi, b) kemutakhiran data dan konsep, c) sumber materi yang digunakan benar baik secara teoritik maupun empirik, d) menciptakan kemandirian belajar dan inovasi, serta e) memberikan motivasi untuk mengembangan diri siswa. Sedangkan pada aspek penyajian materi meliputi a) materi yang disajikan harus runtut, lugas, koheren, mudah dimengerti dan interaktif, b) menariknya penyajian materi, c) ilustrasi materi baik tulisan maupun gambar sesuai dengan tingkat perkembangan usia pembaca, d) tidak mengandung unsur pornografi, e) sajian materi dapat memberi stimulasi kepada siswa agar berpikir secara kritis, kreatif, dan inovatif; serta f) terdapat pengetahuan kontekstual antara materi dan peristiwa sehari-hari sehingga pembaca dapat mengalami dan memperoleh hal yang positif.

Tujuan penelitian ini adalah untuk menganalisis kesesuaian antara bab himpunan yang terdapat di dalam buku teks siswa matematika untuk SMP/MTs Kelas VII Kurikulum 2013 Edisi Revisi pada materi himpunan yang ditulis oleh Atang Supriadi dan diterbitkan oleh Grafindo Media Pratama pada tahun 2019 dengan empat kriteria kurikulum 2013 yang telah disebutkan.

\section{Metode}

Penelitian ini menggunakan penelitian kualitatif deskriptif (Hadi, 2017). Subyek yang akan diteliti adalah Bab Himpunan pada buku teks siswa matematika untuk SMP/MTs Kelas VII Kurikulum 2013 Edisi Revisi yang ditulis oleh Atang Supriadi dan diterbitkan oleh Grafindo Media Pratama pada tahun 2019. Metode observasi merupakan teknik pengumpulan data yang digunakan (Ida, 2018). Lembar penskoran yang digunakan dalam menganalisis 
kesesuain buku teks siswa matematika untuk SMP/MTs Kelas VII Kurikulum 2013 Edisi Revisi pada materi himpunan yang ditulis oleh Atang Supriadi dan diterbitkan oleh Grafindo Media Pratama pada tahun 2019 dengan kriteria kurikulum 2013 terdiri dari 28 butir pernyataan yaitu 3 pernyataan sesuai dengan Standar Kompetensi Lulusan (SKL), 6 pernyataan sesuai dengan pendekatan saintifik, 8 pernyataan sesuai dengan penilaian autentik, dan 11 pernyataan sesuai dengan aspek materi dan penyajian materi. Sedangkan untuk metode analisisnya dengan cara mendeskripsikan dan melihat kesesuaian materi himpunan sesuai dengan Standar Kompetensi Lulusan (SKL), pendekatan saintifik, penilaian autentik, aspek materi dan penyajian materi berdasarkan lembar penskoran kesesuaian buku. Skala penilaian yang digunakan adalah 1 sampai 4. Skor 1 untuk sangat kurang valid, skor 2 untuk kurang valid, skor 3 untuk valid, dan skor 4 untuk sangat valid. Setelah skor telah dijumlahkan, maka diperoleh persentase kesesuaian buku.

Kesesuaian dengan Standar Kompetensi Lulusan (SKL)

1. Terdapat ranah pengetahuan (kognitif) pada Bab Himpunan

2. Terdapat ranah sikap (afektif) pada Bab Himpunan

3. Terdapat ranah keterampilan (psikomotor) pada Bab Himpunan Kriteria Pendekatan Saintifik

1. Penemuan konsep yang terdapat dalam materi himpunan dengan peristiwa nyata dalam kehidupan sehari-hari

2. Dalam penemuan konsep, materi himpunan tersebut terdapat kalimat mengayomi atau mengajak siswa untuk mengamati permasalahan beserta penyelesaiannya

3. Materi himpunan yang terdapat dalam buku, memberi ide kepada siswa untuk bertanya

4. Materi himpunan yang terdapat dalam buku menggiring siswa untuk menalar

5. Materi himpunan yang terdapat dalam buku, memberi dorongan siswa untuk mencoba

6. Materi himpunan yang terdapat dalam sub bab, mengarahkan siswa agar dapat menyimpulkan konsep yang telah diperoleh dari tahap-tahap sebelumnya

Penilaian Autentik

1. Penilaian kognitif/ pengetahuan ada dalam pada Bab Himpunan

2. Penilaian afektif / sikap ada dalam pada Bab Himpunan

3. Penilaian psikomotor/ keterampilan ada dalam pada Bab Himpunan

4. Terdapat soal tipe exercise dalam Bab Himpunan

5. Terdapat soal berbasis masalah dalam Bab Himpunan

6. Terdapat soal challenge dalam Bab Himpunan

7. Terdapat soal berbasis proyek dalam Bab Himpunan

8. Terdapat soal yang memiliki tingkat kesulitan rendah sampai tingkat kesulitan tinggi pada uji kompetensi dalam Bab Himpunan

Kelayakan Buku (Aspek Materi dan Penyajian Materi)

1. Tetap terjaganya kebenaran dan kakuratan materi

2. Kemutakhiran data dan konsep

3. Sumber materi yang digunakan benar baik secara teoritik maupun empirik 
4. Menciptakan kemandirian belajar dan inovasi

5. Memberikan motivasi untuk mengembangan diri siswa

6. Materi yang disajikan harus runtut, lugas, koheren, mudah dimengerti dan interaktif

7. Menariknya penyajian materi

8. Ilustrasi materi baik tulisan maupun gambar sesuai dengan tingkat perkembangan usia pembaca

9. Tidak mengandung unsur pornografi

10. Sajian materi dapat memberi stimulasi kepada siswa agar berpikir secara kritis, kreatif, dan inovatif

11. Terdapat pengetahuan kontekstual antara materi dan peristiwa seharihari sehingga pembaca dapat mengalami dan memperoleh hal yang positif

\section{Hasil dan Pembahasan}

Setelah dilakukan penskoran, untuk butir instrumen berdasarkan kriteria Standar Kompetensi Lulusan (SKL), Bab Himpunan yang terdapat di dalam buku teks siswa matematika untuk SMP/MTs Kelas VII Kurikulum 2013 Edisi Revisi yang ditulis oleh Atang Supriadi dan diterbitkan oleh Grafindo Media Pratama pata tahun 2019 memperoleh hasil skor yaitu 11 dari total 12. Hal ini menunjukkan bahwa, Bab himpunan yang terdapat di dalam buku siswa tersebut memiliki rata-rata 3,67. Sehingga didapatkan persentase sebesar 91,67 \% materi himpunan pada buku tersebut sesuai dengan Standar Kompetensi Lulusan (SKL) dengan kategori sangat baik. Dalam Bab tersebut, kompetensi dasar pada ranah sikap (afektif) dari segi sosial ataupun spiritual belum terpapar dengan jelas, sehingga pada bab himpunan ini tidak memperlihatkan kesesuaian dengan Kompetensi Inti (KI) ranah sikap. Hal ini mengakibatkan bab himpunan masih kurang mendukung dalam pencapaian Standar Kompetensi Lulusan (SKL) pada dimensi sikap. Sedangkan untuk Kompetensi Dasar (KD) ranah pengetahuan dan keterampilan, sudah tercantum di dalam bab himpunan ini. Sehingga, isi dari bab himpunan sudah dapat mendukung dalam pencapaian Kompetensi Dasar (KD) pengetahuan dan keterampilan. Oleh karena itu, bab ini dapat menunjang dalam pencapaian Standar Kompetensi Lulusan (SKL) di segi pengetahuan dan keterampilan.

Kemudian, untuk skor kesesuaian pendekatan saintifik dan materi himpunan dalam buku teks siswa tersebut memperoleh skor 21 dari total 24 skor. Hal ini menunjukkan bahwa, Bab Himpunan memiliki rata-rata 3,5. Sehingga menghasilkan persentase sebesar 87,5\% materi himpunan pada buku tersebut sesuai dengan pendekatan saintifik dengan kategori sangat baik. Siswa diberi kesempatan menemukan konsep materi himpunan berdasarkan masalah konkret yang diberikan, sehingga pemahaman siswa sangat diperlukan. Untuk tahapan pada pendekatan saintifik akan terlihat ketika terdapat perintah dalam penyelesaian soal/ masalah yang diberikan melalui kegiatan pengamatan dalam bab himpunan. Dalam proses tahapan pengamatan masalah, siswa akan menggunakan kemampuan bernalarnya untuk menambah pemahaman siswa, dilanjutkan dengan 
mencoba menyelesaikan dan

menyimpulkan dari hasil penyelesaian masalah. Sedangkan untuk tahapan menanya masih belum jelas terlihat dalam bab himpunan ini. Tahap menanya ini akan dipengaruhi pada pemahaman masingmasing siswa. Untuk bab himpunan ini juga dapat dipakai dalam pembelajaran model Discovery Learning (DL), Problem Based Learning (PBL), dan Project Based Learning.

Selanjutnya, untuk instrumen penskoran kesesuaian antara kriteria penilaian autentik dengan buku teks siswa matematika untuk SMP/ MTs Kelas VII Kurikulum 2013 Edisi Revisi pada materi himpunan yang ditulis oleh Atang Supriadi dan diterbitkan oleh Grafindo Media Pratama pada tahun 2019 memperoleh skor 26 poin dari total skor 32 poin memiliki rata-rata 3,25. Sehingga menghasilkan persentase sebesar 81,25\% buku tersebut sesuai dengan penilaian autentik dengan kategori baik. Soal-soal yang terdapat di dalam bab himpunan dapat dipakai untuk instrumen penilaian autentik. Dalam bab himpunan, soal yang digunakan sudah bisa mengukur kompetensi pengetahuan, sikap, dan keterampilan siswa. Penilaian sikap terdapat pada redaksi penguatan karakter yang tercantum di dalam buku meski hanya beberapa redaksi. Dan juga terlihat melalui perintah diskusi, sehingga guru diberi kesempatan untuk mengamati aktivitas siswa dalam proses pembelajaran.

Sedangkan, untuk instrumen kesesuaian pada kriteria kelayakan materi dari aspek materi dan penyajian materi skor yang didapatkan adalah 40 dari total 44 skor. Hal ini menunjukkan bahwa, Bab Himpunan pada buku teks siswa matematika untuk
SMP/ MTs Kelas VII Kurikulum 2013 Edisi Revisi pada yang ditulis oleh Atang Supriadi dan diterbitkan oleh Grafindo Media Pratama pata tahun 2019 memiliki ratarata 3,64. Sehingga menghasilkan persentase sebesar 90,91\% buku tersebut sesuai dengan kelayakan materi dari aspek materi dan penyajian materi dengan kategori sangat baik. Dari aspek materi yang terdapat di dalam bab himpunan masih terjaga kebenaran dan keakuratannya. Kemutakhiran data dan konsep dan juga sumber yang digunakan benar baik secara teoritik maupun empirik. Namun, dalam bab himpunan ini masih kurang jelas motivasi untuk mengembangkan diri siswa. Sedangkan dalam aspek penyajian materi sudah runtut, lugas, koheren dan mudah dimengerti. Penyajian materi dengan warna-warna lembut dan gambar yang sesuai dengan tingkat perkembangan siswa membuat bab ini menarik untuk dibaca. Dalam bab himpunan, juga terdapat beberapa pengetahuan kontekstual sehingga siswa bisa memperoleh hal positif dari peristiwa tersebut. Hanya saja, dalam bab himpunan ini, belum terlihat jelas hal membuat siswa berpikir secara kreatif dan inovatif.

Bisa dilihat bahwa buku teks yang dianalisis sudah cukup baik untuk dijadikan sebagai sumber referensi yang digunakan dalam pembelajaran matematika, walaupun ada beberapa kekurangan atau ketidaksesuaian dengan Kurikulum 2013, yaitu kompetensi dasar dari ranah afektif segi sosial dan spiritual belum terlihat dengan jelas, tahap menanya juga belum terlihat dengan jelas, dan masih kurang 
jelas motivasi untuk mengembangkan diri siswa.

Hasil penelitian ini sejalan dengan penelitian yang dilakukan oleh Rizkianto \& Santosa (2017), Ramda (2017), Ramda, Kurnila, \& Jundu (2018), dan Rohim (2020). Hasil penelitian menyatakan bahwa masih terdapat kekurangan atau ketidaksesuaian buku teks matematika dengan tuntutan kurikulum 2013.

\section{Penutup}

Adapun kesimpulan yang diperoleh dari penelitian yang sudah dilakukan yaitu kesesuaian antara Bab himpunan di dalam buku teks siswa matematika untuk SMP/ MTs Kelas VII Kurikulum 2013 Edisi Revisi yang ditulis oleh Atang Supriadi dan diterbitkan oleh Grafindo Media Pratama pata tahun 2019 dengan Standar Kompetensi Lulusan (SKL) termasuk kategori sangat baik memperoleh persentase 91,67\%, dengan pendekatan saintifik termasuk kategori sangat baik memperoleh persentase $87,25 \%$, dengan penilaian autentik dengan kategori baik memperoleh persentase 81,25\%, dan dengan kelayakan materi dengan kategori sangat baik memperoleh persentase 90,9\%.

Berdasarkan kesimpulan mengenai analisis kesesuaian Bab himpunan di dalam buku teks siswa kelas VII SMP/ MTs Kurikulum 2013 dilihat dari 4 kriteria kurikulum 2013, maka adapun sarannya adalah : 1) Dari hasil analisis kesesuaian, buku ini bisa dijadikan sebagai masukan dan pertimbangan bagi pembaca/ pengguna buku terkhusus pada bab himpunan untuk menentukan buku teks siswa yang dapat digunakan untuk pembelajaran sesuai dengan kurikulum yang ada, 2) Ketidaksesuaian yang terdapat pada bab himpunan bisa dijadikan perbaikan bagi penulis ataupun penerbit, 3) Untuk peneliti yang lain, dianjurkan agar lebih menguatkan acuan untuk setiap indikator yang terdapat pada kurikulum 2013 yang akan dimanfaatkan saat proses penelitian.

\section{Daftar Pustaka}

Abi, A. M. (2017). Integrasi etnomatematika dalam kurikulum matematika sekolah.JPMI (Jurnal Pendidikan Matematika Indonesia), 1(1), 1-6.

Afriansyah, E. A., Herman, T., \& Dahlan, J. A. (2021, February). Critical thinking skills in mathematics. In Journal of Physics: Conference Series (Vol. 1778, No. 1, p. 012013). IOP Publishing.

Amirono. (2016). Evaluasi \& Penilaian Pembelajaran Kurikulum 2013. Yogyakarta : Gava Media.

Anwar, M. S., Choirudin, C., Ningsih, E. F., Dewi, T., \& Maseleno, A. (2019). Developing an interactive mathematics multimedia learning based on ispring presenter in increasing students' interest in learning mathematics. AlJabar: Jurnal Pendidikan Matematika, 10(1), 135-150.

Arikunto, S. (2013). Prosedur Penelitian Suatu Pendekatan Praktik. Jakarta: Rineka Cipta.

Brassler, M., \& Dettmers, J. (2017). How to enhance interdisciplinary competence-interdisciplinary problem-based learning versus interdisciplinary project-based 
learning. Interdisciplinary Journal of Problem-Based Learning, 11(2), 12.

Elias, M. J. (2019). What if the doors of every schoolhouse opened to socialemotional learning tomorrow: Reflections on how to feasibly scale up high-quality SEL. Educational Psychologist, 54(3), 233-245.

Fatimah, I. F. (2021). Strategi Inovasi Kurikulum. EduTeach: Jurnal Edukasi dan Teknologi Pembelajaran, 2(1), 1630.

Glasnovic Gracin, D. (2018). Requirements in mathematics textbooks: a fivedimensional analysis of textbook exercises and examples. International journal of mathematical education in science and technology, 49(7), 10031024.

Habiby, W. N. (2017). Manajemen Adaptasi Pembelajaran Kurikulum 2013 ke Kurikulum 2006 (KTSP) pada Siswa Kelas I SDN Sondakan Surakarta. Profesi Pendidikan Dasar, 4(2), 180-189.

Hadi, S. (2017). Pemeriksaan Keabsahan

Data Penelitian Kualitatif Pada Skripsi. Jurnal Ilmu Pendidikan, 22(1).

Hakim, L. (2017). Analisis perbedaan antara kurikulum KTSP dan kurikulum 2013. Jurnal IImiah DIDAKTIKA: Media Ilmiah Pendidikan dan Pengajaran, 17(2), 280-292.

Hartono. (2012). Statistik untuk Penelitian.

Pekanbaru: Zanafa Publishing.

Hildani, T., \& Safitri, I. (2021). Implementasi Pembelajaran Matematika Berbasis Kurikulum Jaringan Sekolah Islam Terpadu (JSIT) Dalam Membentuk Karakter Siswa. Jurnal Cendekia: Jurnal Pendidikan Matematika, 5(1), 591-606.
Ibáñez, M. B., \& Delgado-Kloos, C. (2018). Augmented reality for STEM learning: A systematic review. Computers \& Education, 123, 109-123.

Ida, R. (2018). Etnografi Virtual Sebagai Teknik Pengumpulan Data dan Metode Penelitian. The Journal of Society and Media, 2(2), 130-145.

In'am, A., \& Hajar, S. (2017). Learning Geometry through Discovery Learning Using a Scientific Approach. International Journal of Instruction, 10(1), 55-70.

Kemendikbud. (2013). Pengembangan Kurikulum 2013. Jakarta : Kemendikbud.

Kurniaman, O., \& Noviana, E. (2017). Penerapan Kurikulum 2013 dalam Meningkatkan Keterampilan, Sikap, dan Pengetahuan. Jurnal Primary, 6( 2), 389-396.

Margana, H. A. (2012). Analisis Kurikulum terhadap Daya Matematik. Mosharafa: Jurnal Pendidikan Matematika, 1(2), 83-90.

Mukhlis, Y. M. (2015). Analisis Buku Siswa Kurikulum 2013 Kelas VII SMP Pelajaran Matematika ditinjau dari Pendekatan Scientiic dan Penilaian Autentik. Skripsi pada Program Studi Pendidikan Matematika Universitas Muhammadiyah Surakarta: Tidak diterbitkan.

Mukminah, M. (2018). Problematika Penerapan Kurikulum 2013 (K13) Pada Madrasah Ibtidaiyah Nurul Ulum Mertak Tombok Praya Kabupaten Lombok Tengah. Jupe: Jurnal Pendidikan Mandala, 3(3), 1-4.

Murdaningsih, S., \& Murtiyasa, B. (2016). An Analysis on Eight Grade 
Mathematics Textbook of New Indonesia Curriculum (K-13) Based on PISA's Framework. Journal of Research and Advances in Mathematics Education, 1(1), 14-27.

Niculescu, R. M. (2020). Teaching and Assessment Focused on Learning in The Context of New Curriculum Concepts. Educația Plus, 27(2), 163171.

Nurdin, Syafruddin, dan Adriantoni. (2016). Kurikulum dan Pembelajaran. Jakarta: Rajawali Pers.

Pardi, M. H. H., \& Mauliddin, M. (2021). Analisis kompetensi pedagogik guru matematika dalam menerapkan kurikulum 2013 di SMA. Journal of Math Tadris (jMt)), 1(01), 55-67.

Permendikbud. (2014). Tentang Penilaian Hasil Belajar oleh Pendidik pada Pendidikan Dasar dan Pendidikan Menengah. Jakarta: Permendikbud.

Ramda, A. H. (2017). Analisis Kesesuaian Materi pada Buku Teks Matematika Kelas VII dengan Kurikulum 2013. Jurnal Pythagoras, 12(1), 12-22.

Ramda, A. H., Kurnila, V. S., \& Jundu, R. (2018). Analisis Kesesuaian Standar Isi Buku Teks Matematika Kelas VIII dengan Kurikulum 2013. Jurnal Eksakta Pendidikan, 2(2), 162-169.

Rapanta, C., Botturi, L., Goodyear, P., Guàrdia, L., \& Koole, M. (2020). Online university teaching during and after the Covid-19 crisis: Refocusing teacher presence and learning activity. Postdigital Science and Education, 2(3), 923-945.

Restian, A., Deviana, T., \& Saputri, Y. N. E. (2020). Pengembangan LKS Berbasis
Kearifan Lokal di Malang Untuk Siswa Kelas IV SD.Scholaria: Jurnal Pendidikan dan Kebudayaan, 10(1), 8591.

Rizkianto, I., \& Santosa, R. H. (2017). Analisis Buku Matematika SMP Kurikulum 2013. Mosharafa: Jurnal Pendidikan Matematika, 6(2), 229-236. Rizqi, M. M., Wijayanti, D., \& Basir, M. A. (2021). Analisis Buku Teks Matematika Materi Himpunan Menggunakan Model Prakseologi. Jurnal IImiah Pendidikan Matematika: Delta, 9(1), 57-76.

Rohim, A. (2020). Analisis Kesalahan Buku Matematika Materi Relasi dan Fungsi Kelas VIII serta Alternatif Penyelesaiannya. Jurnal Edukasi: Kajian Ilmu Pendidikan, 6(2), 259-268.

Rumahlatu, D., Huliselan, E. K., \& Takaria, J. (2016). An Analysis of the Readiness and Implementation of 2013 Curriculum in The West Part Of Seram District, Maluku Province, Indonesia. International Journal of Environmental \& Science Education, 11(12), 56625675.

Sari, N. E., \& Suryana, D. (2019). Thematic Pop-Up Book as a Learning Media for Early Childhood Language Development. Jurnal Pendidikan Usia Dini, 13(1), 43-57.

Subagiyo, L., \& Safrudiannur, S. (2014). Implementasi Kurikulum 2013 pada Jenjang SD, SMP, SMA, dan SMK di Kalimantan Timur Tahun 2013/2014. Jurnal Pancaran, 3(4), 131-144.

Suharyono, E., \& Rosnawati, R. (2020). Analisis Buku Teks Pelajaran Matematika SMP ditinjau dari Literasi 
Matematika. Mosharafa: Jurnal Pendidikan Matematika, 9(3), 451-462. Sunuyeko, N., Lani, A., \& Wahyuni, L. (2017). Analisis kebutuhan guru dalam pengimplementasian kurikulum 2013 di Sekolah Dasar. Sekolah Dasar: Kajian Teori dan Praktik Pendidikan, 25(1), 1826.

Sutiarso, S. (2020). Keterlaksanaan Penerapan Pendekatan Saintifik pada Pembelajaran Matematika. Jurnal Pendidikan Matematika Unila, 8 (2), 57-67.

Suyadi \& Dahlia. (2017). Implementasi dan Inovasi Kurikulum 2013. Bandung: PT. Remaja Rosdakarya.

Torkos, H. (2020). The Place of Outdoor Learning Activities in The Romanian Core Procurement Curriculum. Educația Plus, 26(1), 276286.

Utari, T., \& Hartono, H. (2019). Muatan penalaran dan pembuktian matematis pada buku teks matematika SMA kelas X Kurikulum 2013. Jurnal Riset Pendidikan Matematika, 6(1), 1-13.

Van Zanten, M., \& van den HeuvelPanhuizen, M. (2018). Opportunity to learn problem solving in Dutch primary school mathematics textbooks. ZDM, 50(5), 827-838.

Widyaharti, M. S., Trapsilasiwi, D., \& Fatahillah, A. (2015). Analisis Buku Siswa Matematika Kurikulum 2013 untuk Kelas X Berdasarkan Rumusan Kurikulum 2013. Jurnal Kadikma, 6(2), 173-184.

Wu, T. T., \& Wu, Y. T. (2020). Applying project-based learning and SCAMPER teaching strategies in engineering education to explore the influence of creativity on cognition, personal motivation, and personality traits. Thinking Skills and Creativity, 35, 100631.

Yunianto, T. (2021). Analisis Kesesuaian Materi IPA Dalam Buku Siswa Kelas IV Semester 1 SD/MI Dengan Kurikulum 2013. Jurnal IImiah Pendidikan Dasar, 8(1), 1-17.

\section{Riwayat Hidup Penulis}

Sri Murniati, S.Pd.

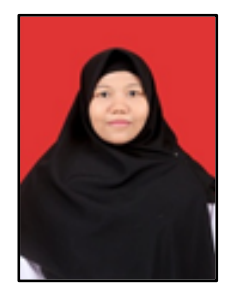

Lahir di Selatpanjang, 17 Februari 1996. Mahasiswa Pascasarjana Universitas Riau. Studi S1 Pendidikan Matematika, Universitas Islam Negeri Sultan Syarif Kasim Riau, lulus tahun 2019.

\section{Yenita Roza, Ph.D.}

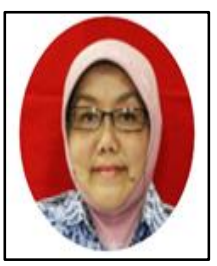

Lahir di Painan, 14 Juni 1963. Merupakan staf pengajar di Universitas Riau. Menyelesaikan pendidikan S1 Pendidikan Matematika IKIP Padang lulus pada tahun 1985, S2 EduTech \& ComEdu Universitas of Kentucky (USA) lulus pada tahun 1990 dan S3 EduTech \& ComEdu Kansas State University (USA) lulus pada tahun 1994.

\section{Dr. Maimunah, M.Si.}

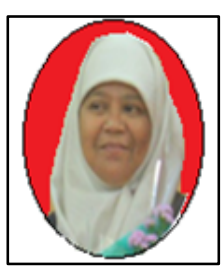

Lahir di Kijang, tanggal 15 Januari 1962. Merupakan staf pengajar di Universitas Riau. Menyelesaikan pendidikan S1 Matematika FMIPA IKIP Padang lulus pada tahun 1986, S2 Matematika FMIPA Universitas Gajah Mada lulus pada tahun 2002 dan S3 Pendidikan Matematika Universitas Negeri Malang lulus pada tahun 2016. 